$\mathrm{Oz}$

$1-1-2012$

\title{
An Architecture of Change: Newtown Creek Wastewater Treatment Plant
}

Richard Olcott

Follow this and additional works at: https://newprairiepress.org/oz

\section{c) (1) $\Theta($}

This work is licensed under a Creative Commons Attribution-Noncommercial-No Derivative Works 4.0 License.

\section{Recommended Citation}

Olcott, Richard (2012) "An Architecture of Change: Newtown Creek Wastewater Treatment Plant," Oz: Vol. 34. https://doi.org/10.4148/2378-5853.1505

This Article is brought to you for free and open access by New Prairie Press. It has been accepted for inclusion in Oz by an authorized administrator of New Prairie Press. For more information, please contact cads@k-state.edu. 


\title{
An Architecture of Change: \\ Newtown Creek Wastewater Treatment Plant
}

\author{
Richard Olcott \\ Ennead Architects
}

Nothing is permanent except change.

- Heraclitus

We live in a time of aging infrastructure and depleted resources. Coupled with these conditions is a heightened consciousness of the need to develop sustainable responses and an imperative to meet environmental responsibilities for our collective, long-term future. While we endeavor to build more sustainably, more responsibly, and more permanently, paradoxically our infrastructure must be constantly in flux: an architecture of change.

In the past, infrastructure was built "for the ages," using the most durable materials and methods. A prime example of this is the vast system of dams, aqueducts, tunnels, and buildings for Croton/Catskill water system, built of granite to last a thousand years. However, in our age of rapidly evolving technologies and efficiencies, we are called upon to do the opposite: to create an architecture that can constantly adapt to changing, unforeseen conditions.

So how does an architect plan for the unknown? What does flexibility mean relative to accommodating the processes that are supported by our infrastructure and on which we depend?

The Newtown Creek Wastewater Treatment Plant is an example of an architectural strategy for ongoing change. It is a 54-acre facility in
1.5 million people in three boroughs, including Lower Manhattan and the East Side, and large portions of Brooklyn and Queens. Sited between industrial areas to the south and east and the Greenpoint residential neighborhood to the west, the site abuts Newtown Creek, a highly polluted waterway used for industrial purposes for generations. The plant has long been considered a "bad neighbor" to the larger community, along with the adjacent Exxon facility that is now a federal Superfund site. It has long been a major goal of New York City's Department of Environmental Protection (DEP) to rectify this very undesirable condition in the middle of the city. Required by the federal government to upgrade the facility to comply with the Clean Water Act, the DEP hired a triventure of the engineering firms: Greeley Hansen, Hazen \& Sawyer, and Malcolm Pirnie. Their task was to design an entirely new facility to be constructed in phases over twenty-five years.

Our engagement began in 1991 after the proposal submitted by the triventure to the New York City Public Design Commission had been rejected. Ennead Architects ( formerly Polshek Partnership Architects) was brought in by some extraordinary individuals at the Department of Environmental Protection who truly believed that "design matters." Our role was to work collaboratively with the engineering triventure to develop a cohesive architectural and urban design strategy that would gain approval from the Public Design Commission.

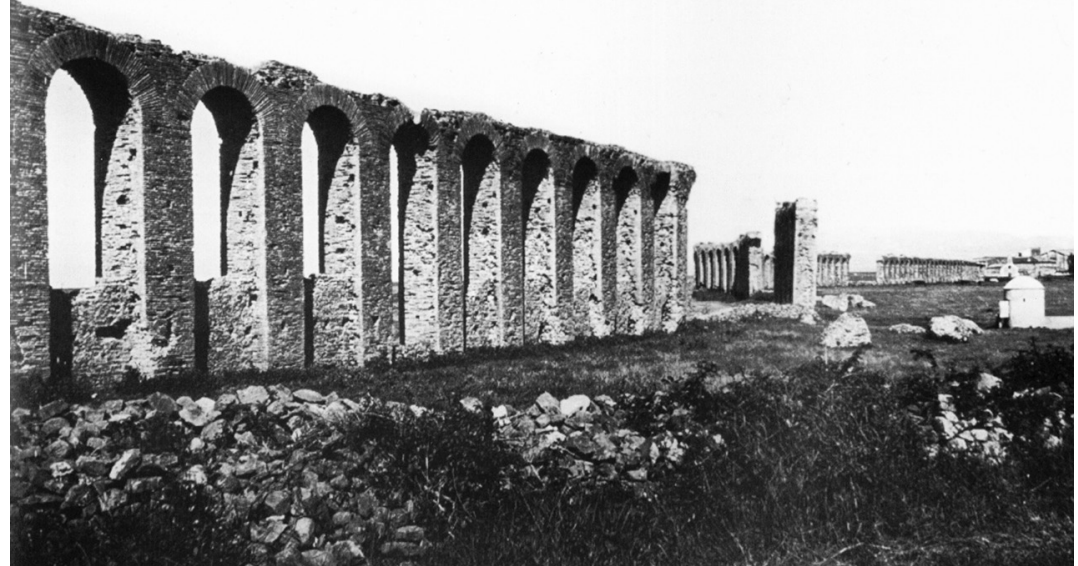

Aqueduct near the Villa of Quintili. Rome, Italy

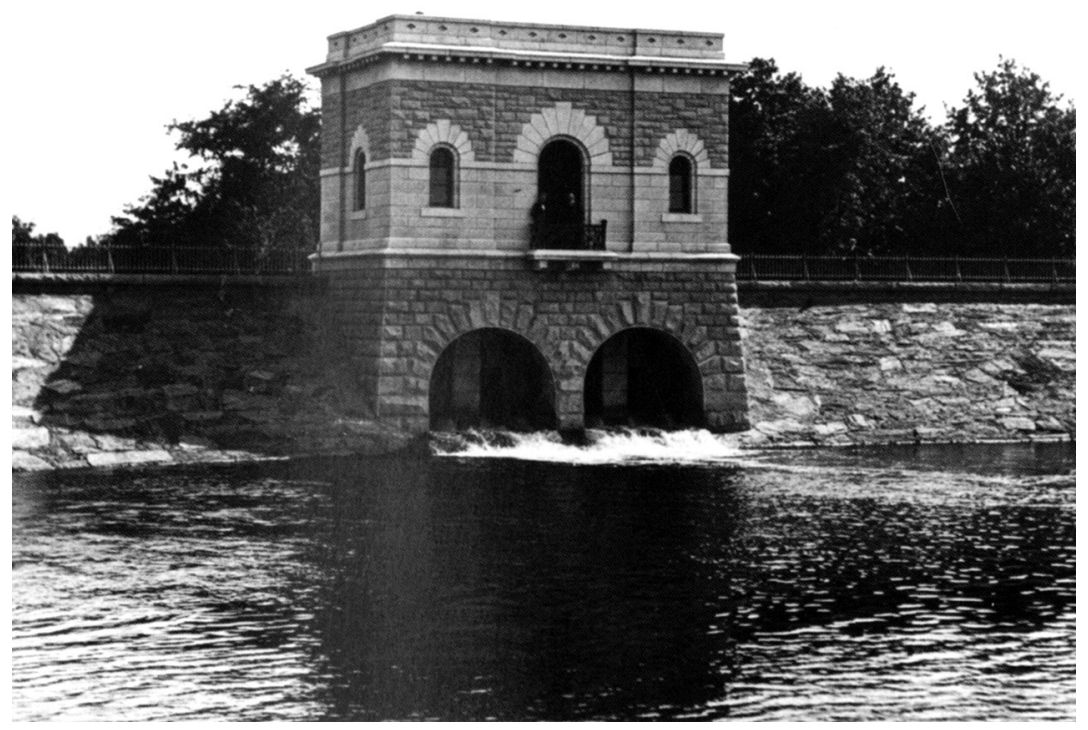

New Croton Aqueduct. Gatehouse at Central Park Reservoir 
Ennead's primary responsibility was to address the general architectural appearance of the buildings with particular attention to the edges of the complex and how it would be viewed from the surrounding neighborhood. In the simplest sense, we were charged with designing architectural enclosure systems for a series of highly complex industrial processes, involving heavy machinery, long spans, toxic materials, corrosive environments, and stringent safety standards. There was very little room for maneuvering in these systems: they were basically dictated to us as fixed entities in need of skins.

The same was true of the site design: given the wastewater treatment process, little flexibility was permitted in the placement of the new structures. As the current facility serves millions of people and operates at capacity twenty-four hours a day, seven days a week, turning off any part, even for a day, was impossible. Therefore, a "musical chairs" scenario of sequential addition and removal of structures was conceived amid a fixed and limited amount of property in which to operate. New buildings and processes needed to be constructed and made operational before the corresponding outmoded piece could be demolished, making a space for the next building in the sequence. This scenario began in 1992 and will continue until 2015 when the last building is complete and the entire facility will have been replaced.

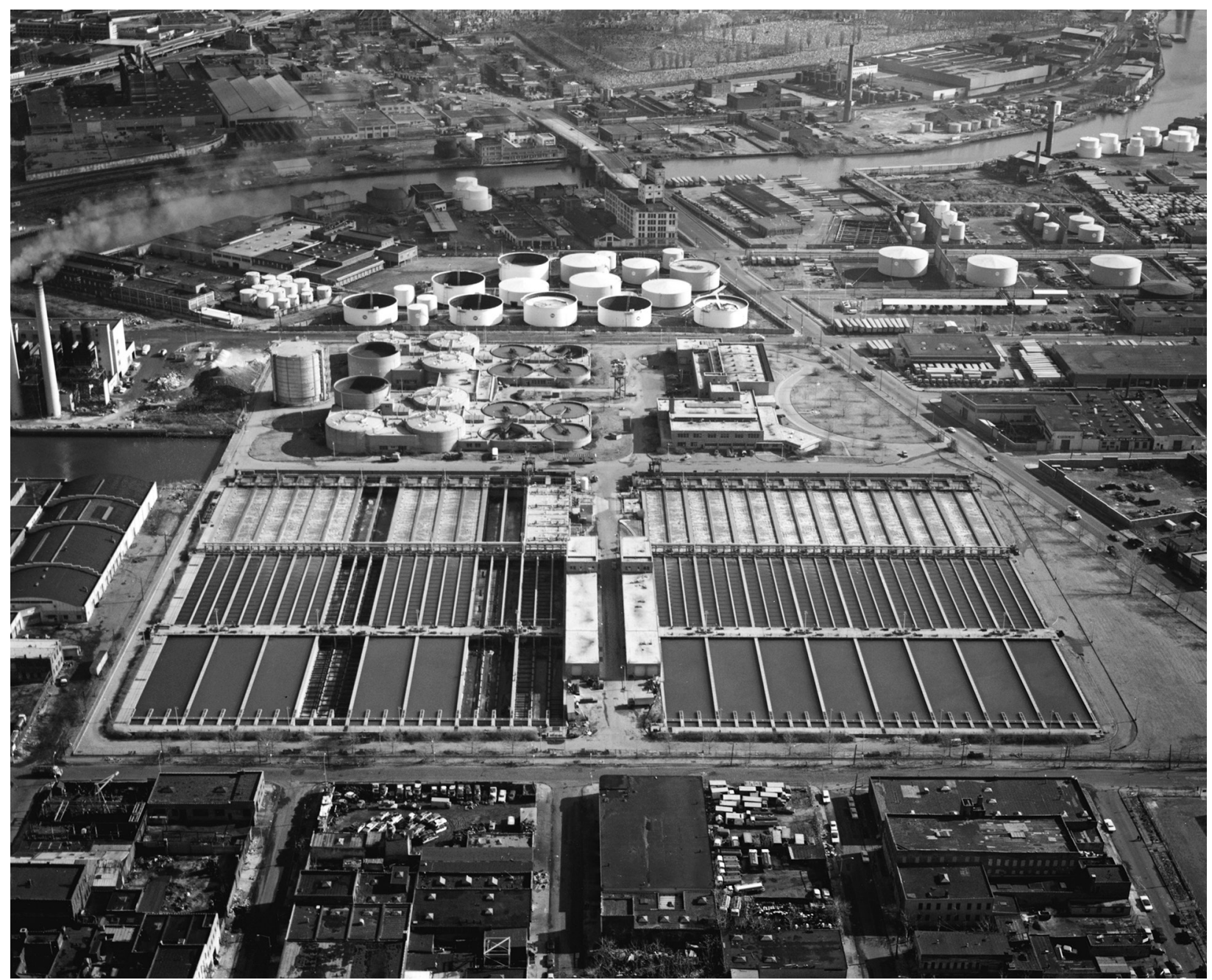

The original Newton Creek Plant

Inherent in this scenario is the reality of technological change and its capacity to therefore cause redesign and reconfiguration of the parts that remain "downstream," whatever the current phase is. In a twenty-five year construction process, some change is virtually certain, and the pace of new innovations and technologies is increasing in this industry, as in so many others. Indeed, the very first building we designed, a small electrical substation that was also used as a material and system mock-up for the whole complex, was torn down in a later phase, due to the design team's adoption of a new process technology that rendered it obsolete.
Thus a supposedly permanent little building, built of rugged and long-lasting materials, which was originally seen as the harbinger of all that was to follow, instead ended up being the first casualty of the bigger idea: the idea of designing for change. 


\section{The "Kit of Parts" Solution}

The solution we developed is really more a strategy than a design: a "kit of parts." Through many iterations of the planning process, we have been working with this kit, which can be applied to the wide variety of massing and forms, technical requirements, scales and urban conditions that are generated by the process itself.

First among the goals of this approach was to achieve clarity and formal integrity (allowing us to dramatize rather than deny the public function) throughout the complex. Making such a vast and complicated range of structures both legible and coherent from the public way surrounding the site helps to clarify its function and scale, from its initial phases through to the ultimate buildout. Through the use of such an ordering system, we hoped to achieve a welcoming and dignified response to the surrounding community, making amends for the last forty years, during which the plant has been a visual eyesore and an olfactory assault.

Just as important to the DEP was to have flexibility and adaptability built into the design. The "kit of parts" allowed us to create unique responses to each problem and to easily adjust or re-design when necessary. At the same time there was the seemingly contradictory requirement of durability and maintainability: the facility's location and the process itself create a corrosive, harsh environment, making a low- or no-maintenance facility a priority. Ease of construction and the use of tried-and-true techniques were also stipulated by the DEP.

So, before we could design buildings, we designed building systems-a series of components that we could assemble into a wide variety of building sizes, scales and forms, and that would meet the many and varied technical requirements including ventilation, daylighting, heavy loading and long spans, and so on.

The primary enclosure systems include stainless steel wall panels and roof cladding and curtain wall systems, both conventionally glazed and structurally glazed. In addition, glazed brick and block in a series of earth, sky, and water tones were selected to codify different functions.

\section{The Evolving Design}

The design and construction process has evolved continuously since 1991, when the first comprehensive master plan was developed.

However, as wastewater treatment technology continued to evolve, it has generated the need for new planning strategies. There have been two major redesigns of the master plan since the initial plan, first in 1998, and then again in 2002. This has resulted not only in new and different architectural forms but entirely new locations for the buildings themselves.

This ongoing process is perhaps best exemplified by the solids-handling building. Originally designed as a series of cylindrical tanks on the north side of the site, this building evolved into the distinctive egg-shaped digester tanks, connected by aerial walkways, and located on the east edge of the site.

The final building complex, the residuals building, is now under construction, to be completed in 2013. Beyond that, there is only the landscape perimeter buffer (as yet unfunded) to be built, and the plant will be complete; or at least the scheme as we designed it will be complete. It seems entirely likely that this could be more like painting the Golden Gate Bridge-you never really finish, you just go back to the beginning and start over again.
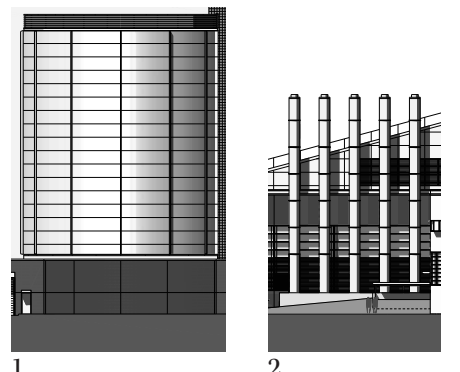

2.

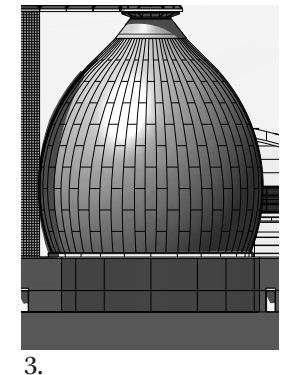

3.

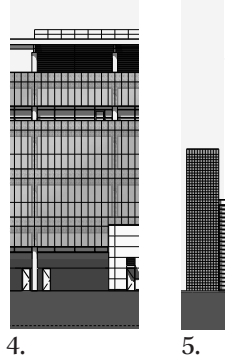

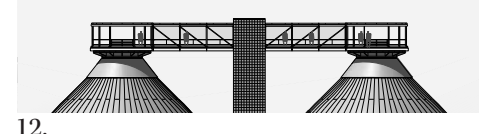

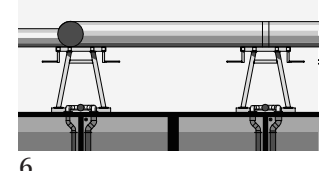

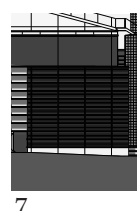

1. Tanks: Stainless steel panel / light blue glazed brick base 2. Stacks: Stainless steel

3. Digesters: Stainless steel roofing/light blue glazed brick base 4. Office/lab building: Structurally glazed curtain wall

5. Stairs and elevators: Green glazed tile

6. Process duct support along site axis: Yellow pylons

7. Louvers: Stainless steel

8. Doors: Stainless steel with canopies

9. Typical buildings: Strip and punched windows/white brick

10. Hi-bay equipment enclosure: Conventional curtainwall/blue brick
8.

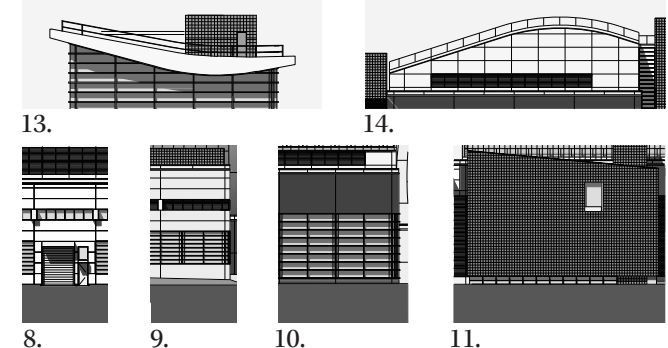

1. Key plant process buildings: Orange glazed tiles

12. Aerial walkways: Glass on stainless steel truss 13. Tank battery buildings: Stainless steel

14. Penthouse at plant perimeter: Stainless steel convex roof and wall panels 
Main Building (1)

A renovation and expansion of the existing main building, this structure contains amenities for personnel, as well as pumps, engines, blowers, boilers, transformers, and other mechanical and electrical gear to run the plant. To educate the public and demystify the process of wastewater management, a visitor's center is located at the southwest corner of the main building near Greenpoint Avenue.

\section{Residuals Building (2)}

This complex houses a series of mechanical and hydraulic systems that remove and treat solid materials from the plant influent. From the com plex, the materials are redirected to other plant facilities or shipped off-site. The low building to the west of the complex directs the plant flow to the process tanks. The stack and canisters to the east of the complex control odors.

\section{Solids Handling Buildings (3)}

This facility consists of two building groups. The first, a digester complex, consists of a series of eight egg-shaped digesters, two sludge tanks, and one gas storage tank, with a low equipment building between the tanks. The second, along Greenpoint Avenue, is a centrifuge building housing dewatering and thickening equipment.

Aeration and Sedimentation Tanks (4)

Most of the water processing at the plant take place in three sets of low tanks. The central and south batteries are existing tanks to be substantially renovated. The north battery is new, on acquired land adjoining the existing site. All tanks will have equipment, minor buildings, piping, and service walkways on top. The aeration tanks are to be covered, some sedimentation tanks open and others covered to control odors. Two control buildings where the processes are regulated are located between the batteries.

\section{Disinfection Building (5)}

This facility contains disinfecting chemicals and dispensing systems and flow control equipment. The building is located over the "contact" tanks. the last step in the water treatment process before release.

Support Building (6)

This new structure houses offices, laboratories, personnel facilities, repair and maintenance shops, and equipment storage areas all to support the function of Newtown Creek and other city water pollution control plants. It will be the only building designed specifically for personnel at the plant.

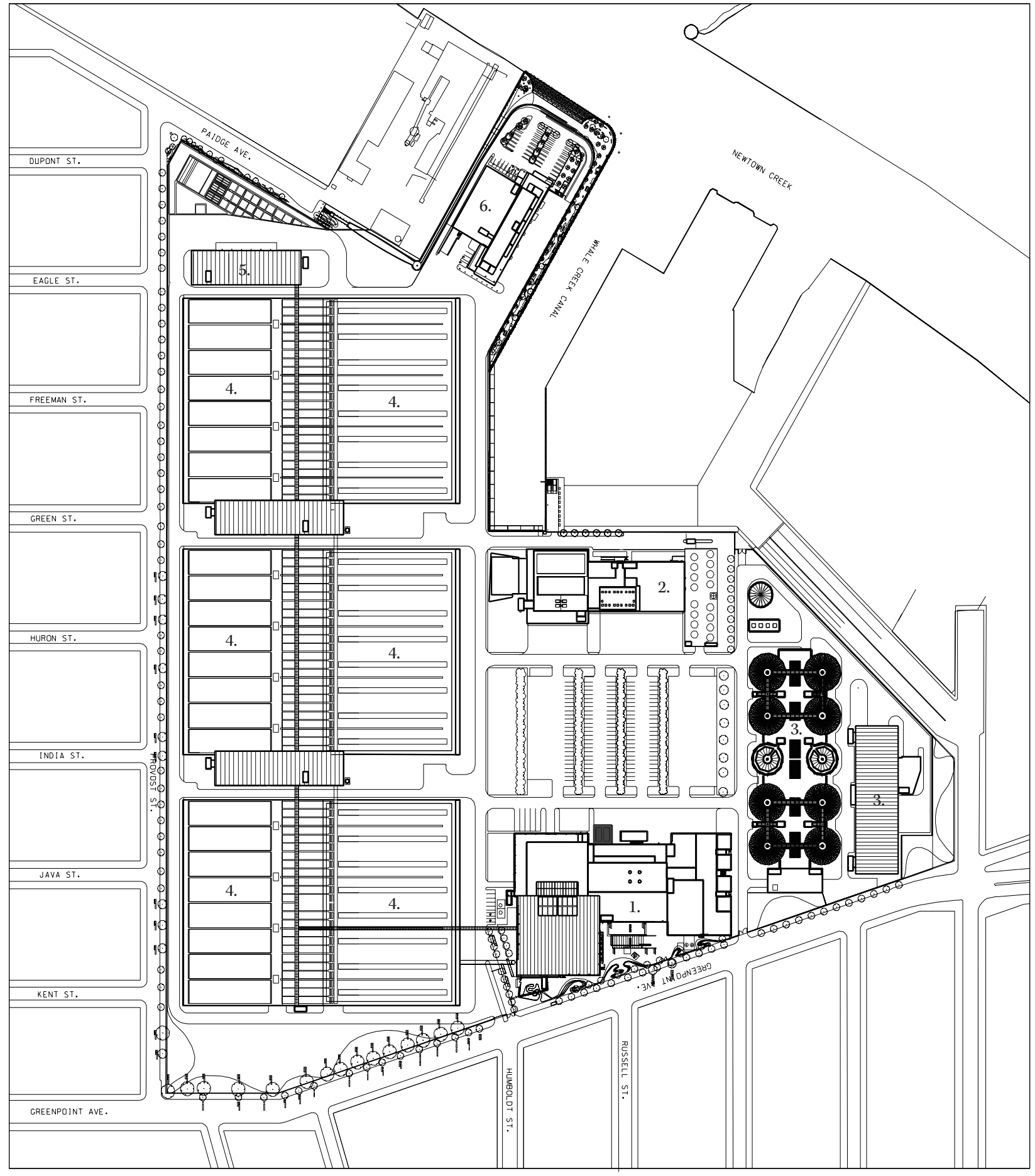

\section{Image Credits}

Fig. 1: Aqueduct near the Villa of Quintili. Rome, Italy. (C) Collection of the Archives, New York City Department of Environmental Protection. Fig. 2: New Croton Aqueduct. Gatehouse at Central Park Reservoir. @ Collection of the New York Historical Society, PR 020.

Fig. 3: Original Plant. @Skyviews. 1 East Main Street, Ramsey, NJ, 07446. 201-327-4300.

Fig. 4: Current Kit-of-Parts. @Ennead Architects.

Fig. 5: Current Master Plan. (Ennead Architects.

Fig. 6: Digesters. @Jeff Goldberg/Esto.

Fig. 7: Main Building. (C)Aislinn Weidele/Ennead Architects.

Fig. 8: Pipes. @Aislinn Weidele/Ennead Architects. 


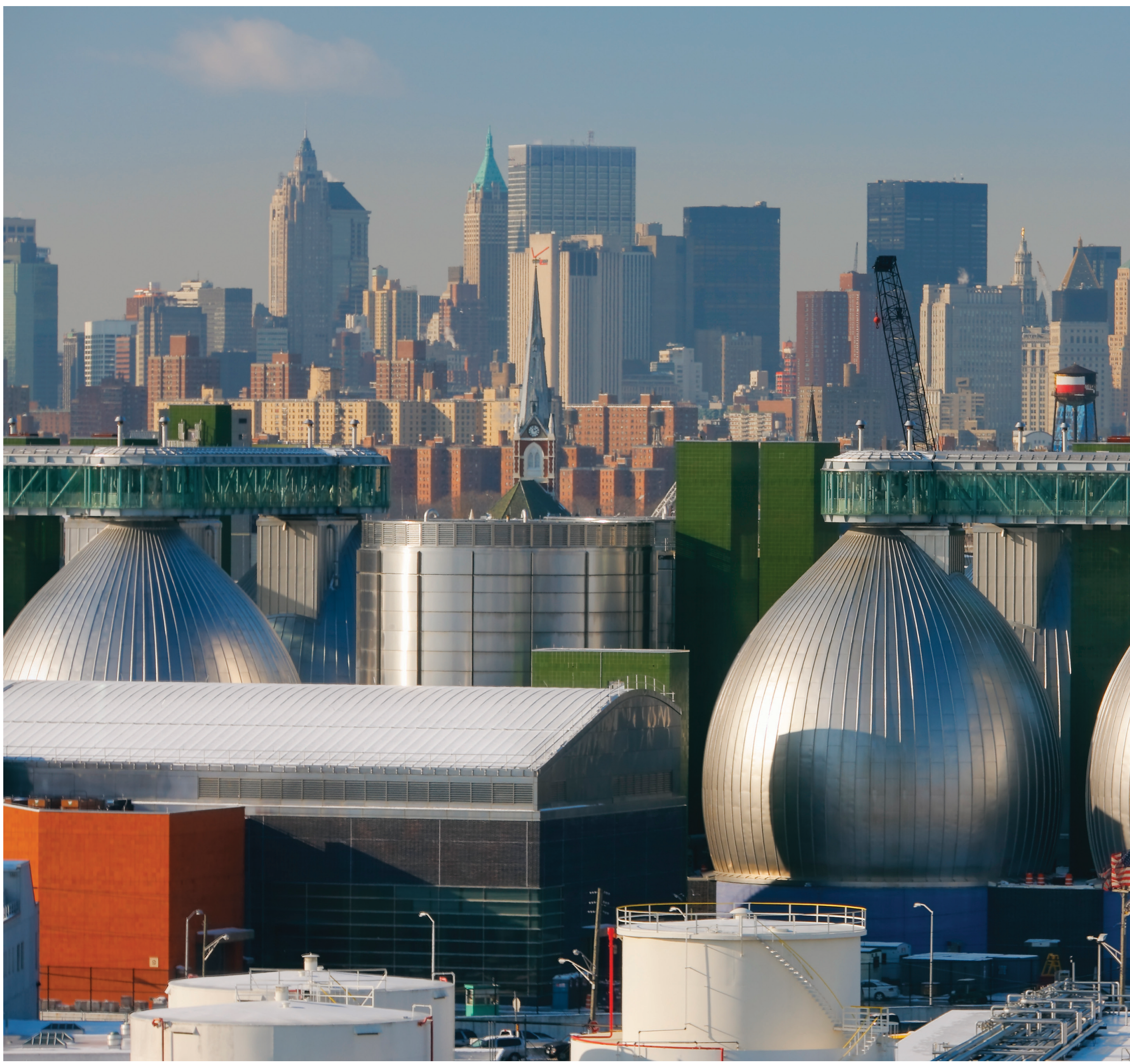


